Artikel Penelitian

\title{
Hubungan Kadar Albumin Serum dengan Lama Rawatan Pasien Stroke Iskemik Akut
}

\author{
Annisa Hidayati Priyono ${ }^{1}$, Hendra Permana ${ }^{2}$, Nita Afriani ${ }^{3}$
}

\begin{abstract}
Abstrak
Kadar albumin serum yang rendah pada penderita stroke iskemik akut dikaitkan dengan perburukan status fungsional, yang mungkin akan mempengaruhi lama rawatan. Tujuan penelitian ini adalah menentukan hubungan antara albumin dan lama rawatan pada pasien stroke iskemik akut. Penelitian ini merupakan studi observasional menggunakan disain potong lintang (cross sectional). Subjek penelitian adalah pasien stroke iskemik akut yang dirawat di bangsal penyakit saraf RS. DR. M. Djamil Padang selama bulan Maret sampai September 2015 dengan onset kurang dari 24 jam yang memenuhi kriteria inklusi. Kadar albumin serum diukur dalam 24 jam pertama rawatan. Kadar albumin serum, derajat stroke, komplikasi dan faktor risiko merupakan variabel yang akan dianalisis dan lama rawatan. Hubungan antar variabel diuji dengan menggunakan uji Chi-square. Hasil dianggap bermakna secara statistik apabila nilai $p<0,05$. Hasil penelitian menunjukkan sebanyak 50 subjek dievaluasi selama penelitian, usia rerata adalah 59 tahun (36-85 tahun), dan rerata kadar albumin serum adalah 3,86 mg/dL. Tidak terdapat hubungan antara kadar albumin serum dan dengan lama rawatan $(p=0,715)$, serta faktor risiko dan lama rawatan $(p=0,76)$, namun terdapat hubungan antara derajat stroke dan lama rawatan $(p<0,001,0 R=12,6)$, serta hubungan antara komplikasi dan lama rawatan $(p<0,001, \mathrm{OR}=17,6)$. Simpulan studi ini adalah tidak terdapat hubungan antara kadar albumin serum dan faktor risiko terhadap lama rawatan, namun terdapat hubungan signifikan antara derajat stroke dan komplikasi terhadap lama rawatan.
\end{abstract}

Kata kunci: stroke iskemik akut, albumin, lama rawatan

\section{Abstract}

In acute ischemic stroke, low level of serum albumin may worsen the functional status, which may affect the length of stay. The objective of this study was to determine the association between serum albumin level and length of stay in acute ischemic stroke patients. This study was conducted using cross-sectional study design. The subjects were acute ischemic stroke patient in neurological ward of DR. M. Djamil Padang Hospital from March to September 2015 within 24 hours of onset. About 50 samples were enrolled the study according to inclusion criteria. Serum albumin level were measured on first 24 hours of admission. Serum albumin, stroke severity, complications and risk factors were variables analyzed in association to length of stay. The association between these variables were examined with Chi-square test. The results were considered as statistically significant if the $p$ value was $<0,05$. Among 50 patients evaluated during the study period, the mean age was 59 years old (36-85 years old) and mean of albumin levels was $3.86 \mathrm{mg} / \mathrm{dL}$. The results showed that there were no significant association between serum albumin level ( $p=$ $0.72)$ and risk factors $(p=0.76)$ on the length of stay, but there were significant association between the stroke severity $(p<0.001, O R=12.6)$ and complications $(p<0.001, O R=17.6)$ on the length of stay. It can be concluded that there was no association between serum albumin levels and a longer treatment, but there is a significant correlation between stroke severity and complications on the length of stay.

Keywords: acute ischemic stroke, albumin, length of stay 
Affiliasi penulis: 1. Prodi Profesi Dokter FK Unand (Fakultas Kedokteran Universitas Andalas Padang), 2. Bagian IImu Penyakit Saraf FK Unand/RSUP Dr M Djamil, Padang, 3. Bagian Histologi FK Unand

Korespondensi: Annisa Hidayati Priyono, Email : ichahdyt@gmaill.com,Telp: 081261987829

\section{PENDAHULUAN}

Stroke merupakan penyebab kematian ketiga di dunia setelah penyakit jantung koroner dan kanker baik di negara maju maupun negara berkembang. Satu dari 10 kematian disebabkan oleh stroke. Secara global, 15 juta orang terserang stroke setiap tahunnya, dimana satu pertiga meninggal dan sisanya mengalami kecacatan permanen. ${ }^{1}$ Sekitar 80-85\% stroke adalah stroke iskemik yang diakibatkan oleh obstruksi pada arteri otak. $^{2}$

Salah satu yang menjadi perhatian pada stroke iskemik dibandingkan dengan tipe stroke lainnya adalah lama rawatan. Masalah ini muncul mengingat pada stroke iskemik diharapkan memiliki prognosis yang lebih baik sehingga penderita hanya membutuhkan perawatan dalam waktu yang lebih singkat. ${ }^{3}$ Lama rawatan dapat dikaitkan dengan biaya yang dikeluarkan untuk pengobatan, komplikasi sekunder serta temuan klinis yang didapatkan selama rawatan. ${ }^{4}$ Lama rawatan juga merupakan indeks kuantitatif yang sangat penting untuk menentukan kualitas dari pelayanan kesehatan di Rumah Sakit. ${ }^{3}$

Peningkatan usia, komplikasi, faktor risiko dan kecacatan tertentu akan mempengaruhi lama rawatan pada pasien stroke iskemik akut. Beberapa studi mengemukakan bahwa komplikasi merupakan faktor independen yang berhubungan dengan lama rawatan. ${ }^{4}$ Semakin lama masa rawatan pasien stroke iskemik menyebabkan semakin banyak komplikasi yang didapat. ${ }^{5}$ Masa rawatan yang lebih singkat dapat meminimalkan tirah baring dan kebutuhan akan alat bantu medis sehingga akan meningkatkan angka kesembuhan pada stroke iskemik akut dan menurunkan kejadian infeksi. ${ }^{4}$

Kadar albumin serum yang rendah merupakan salah satu penanda status nutrisi yang dikaitkan dengan perburukan status fungsional, hasil terapi yang buruk dan peningkatan angka mortalitas. Terdapat hubungan yang signifikan antara hipoalbuminemia dan peningkatan risiko komplikasi, infeksi, lama rawatan dan mortalitas. ${ }^{6}$ Albumin plasma dalam dosis tinggi dapat menjadi neuroprotektor yang menjanjikan terhadap stroke iskemik dengan mengurangi duapertiga dari total volume infark dan mengurangi tigaperempat edema otak, memperbaiki edema otak, meningkatkan aliran darah ke daerah otak yang mengalami krisis perfusi, meningkatkan perfusi mikrovaskuler, mengurangi adhesi elemen darah pasca iskemik dan membantu mengangkut asam lemak bebas yang penting setelah iskemia berakhir. ${ }^{7}$

Belum terdapat hubungan yang jelas antara kadar albumin serum dengan lama rawatan pada pasien stroke iskemik akut. Oleh karena itu perlu dilakukan penelitian untuk mengetahui hubungan antara kadar albumin serum dan lama rawatan pasien stroke iskemik akut.

\section{METODE}

Penelitian yang dilakukan adalah penelitian analitik observasional (observational analytic study) dengan desain studi potong lintang (cross-sectional). Populasi penelitian ini adalah seluruh pasien stroke iskemik akut yang dirawat inap di bangsal penyakit saraf Rumah Sakit Dr M Djamil Padang pada bulan Maret sampai September 2015. Pada penelitian ini dievaluasi pasien stroke iskemik akut yang didiagnosis dalam 24 jam dan dirawat inap di bangsal penyakit saraf RS. Dr. M Djamil, Padang. Kadar albumin serum diambil dalam 24 jam pertama rawatan. Pasien yang meninggal atau meminta dipulangkan oleh sebab tertentu selain medis dikeluarkan dari penelitian. Pasien yang memiliki riwayat penyakit infeksi atau penyakit yang dapat mempengaruhi kadar albumin serum sebelum didiagnosis stroke juga tidak diikutsertakan dalam penelitian ini.

Diagnosis stroke iskemik akut ditegakkan oleh dokter spesialis saraf berdasarkan gejala klinis yang didukung oleh skala stroke Gajah Mada. Kadar albumin serum diukur dengan menggunakan autoanalyzer. Hasil pengukuran albumin dikategorikan menjadi hipolabuminemia $(<3,5 \mathrm{~g} / \mathrm{dL})$ dan normal $(\geq 3,5$ $\mathrm{mg} / \mathrm{dL}$ ). Selain itu juga dianalisis faktor perancu yang dapat mempengaruhi lama rawatan, yaitu derajat stroke, komplikasi, dan faktor risiko stroke. Derajat stroke diukur dengan menggunakan instrumen NIHSS 
score yang kemudian dikategorikan menjadi ringan $(\leq 5)$ dan sedang berat $(>5)$. Komplikasi yang dianalisis adalah komplikasi yang didapatkan selama masa rawatan, yang relatif sering terjadi, dapat diberikan intervensi medis, serta dapat dikaitkan dengan outcome penderita stroke iskemik, yaitu penyakit infeksi, ulkus peptikum, deep veinthrombosis, tromboemboli, konstipasi, nyeri otot dan sendi, disfagia. Faktor risiko adalah penyakit yang sudah didiagnosis sebelum terjadinya stroke dan menyertai keluhan utama.Faktor risiko yang dianalisa adalah hipertensi, penyakit hati ringan, penyakit jantung ringan, penyakit ginjal ringan, penyakit metabolik ringan, dibetes melitus, peningkatan kolestrol serum (dislipidemia).Pasien dengan penyakit kanker atau penyakit jantung berat dikeluarkan dari penelitian.

Pasien dengan stroke iskemik akut yang didiagnosis dalam 24 jam onset, diukur kadar albumin serum dan derajat stroke pada hari kedua rawatan. Usia dan faktor risiko didapatkan dari data rekam medis pasien. Lama rawatan, komplikasi diobservasi secara langsung sampai pasien tersebut diperbolehkan untuk pulang. Kemudian data diolah dan danalisis secara komputerisasi uji Chi-square dengan nilai $p<0,05$ dianggap bermakna secara statistik.

\section{HASIL}

Dari 161 pasien stroke iskemik yang dirawat selama penelitian didapatkan 50 subjek penelitian yang memenuhi kriteria inklusi dan eksklusi.

Berdasarkan Tabel 1 didapatkan bahwa usia terendah adalah 36 tahun dan usia tertua adalah 85 tahun. Kejadian stroke iskemik lebih banyak terjadi pada usia kurang dari sama dengan 65 tahun, yaitu sebanyak 36 subjek $(72,0 \%)$ sementara subjek yang berumur lebih dari 65 tahun sebanyak 14 subjek $(28,0 \%)$. Pasien stroke iskemik akut berjenis kelamin laki-laki lebih banyak daripada subjek wanita, yaitu sebesar 33 subjek $(66,0 \%)$, sedangkan wanita 17 subjek $(34,0 \%)$.
Tabel 1.Distribusi frekuensi pasien stroke iskemik akut

\begin{tabular}{lccc}
\hline \multicolumn{1}{c}{ Karakteristik } & $\mathbf{f}$ & $\%$ & Mean \\
\hline Usia & & & 59,26 \\
$\quad 65$ tahun & 36 & 72,0 & \\
$\quad>65$ tahun & 14 & 28,0 & \\
Jenis Kelamin & & & - \\
$\quad$ Laki-laki & 33 & 66,0 & \\
$\quad$ Perempuan & 17 & 34,0 & \\
Albumin serum & & & 3,86 \\
$\quad<3,5$ g/dl & 9 & 18,0 & \\
$\quad \geq 3,5$ g/dl & 41 & 82,0 & \\
Derajat stroke (NIHSS) & & & 8,3 \\
$\quad$ Ringan ( $\geq 5)$ & 24 & 48,0 & \\
$\quad$ Sedang-berat $(>5)$ & 26 & 52,0 & \\
Komplikasi & & & - \\
$\quad$ Ada & 13 & 26,0 & \\
$\quad$ Tidak ada & 37 & 74,0 & \\
Faktor risiko & & & - \\
$\quad$ Ada & 34 & 68,0 & \\
Tidak ada & 16 & 32,0 & \\
Lama rawatan & & & 14 \\
$\quad$ >7 hari & 23 & 46,0 & \\
$>7$ hari & 27 & 54,0 & \\
\hline
\end{tabular}

Sebanyak 41 subjek (82\%) memiliki kadar albumin serum yang normal $(\geq 3,5 \mathrm{~g} / \mathrm{dl})$, sedangkan 9 subjek lainnya (18\%) termasuk dalam kategori hipoalbuminemia $(<3,5 \mathrm{~g} / \mathrm{dl})$. Berdasarkan derajat keparahan stroke yang diukur dengan skor NIHSS, sebagian besar pasien memiliki derajat keparahan sedang-berat (26 subjek, 52\%), sedangkan 24 subjek lainya (48\%) memiliki derajat keparahan stroke yang ringan.

Sebagian besar subjek tidak memiliki komplikasi selama masa rawatan (37 subjek, $74 \%$ ), sedangkan 13 subjek lain (26,0\%) mengalami komplikasi selama masa rawatan stroke iskemik akut. Komplikasi tersebut meliputi 1 subjek (2,0\%) memiliki komplikasi ulkus dekubitus, 4 subjek $(8,0 \%)$ memiliki komplikasi HAP (Hospital Acquired Pneumonia), tiga subjek $(6,0 \%)$ memiliki komplikasi Infeksi Saluran Kemih (ISK), dua subjek (4,0\%) memiliki komplikasi CAP (Community Acquired Pneumonia), satu subjek 
$(2,0 \%)$ memiliki komplikasi penyakit paru, satu subjek $(2,0 \%)$ memiliki komplikasi ISK, HAP, dan ulkus dekubitus serta satu subjek $(2,0 \%)$ memiliki komplikasi HAP dan ulkus dekubitus.

Berdasarkan ada tidaknya faktor risiko pada penelitian ini, sebanyak didapatkan 34 subjek $(68,0 \%)$ memiliki faktor risiko seperti hipertensi, diebetes melitus, transient ischaemic attack, penyakit jantung dan vertigo. Sedangkan 16 subjek $(32,0 \%)$ tidak memiliki riwayat menderita penyakit tersebut sebelumnya.

Tabel 2. Hubungan kadar albumin serum dengan lama rawatan pasien stroke iskemik akut

\begin{tabular}{|c|c|c|c|c|c|c|c|}
\hline \multirow{3}{*}{$\begin{array}{l}\text { Kadar } \\
\text { albumin } \\
\text { serum }\end{array}$} & \multicolumn{4}{|c|}{ Lama rawatan } & \multirow{2}{*}{\multicolumn{2}{|c|}{ Total }} & \multirow{3}{*}{$\mathbf{p}$} \\
\hline & \multicolumn{2}{|c|}{$\leq 7$ hari } & \multicolumn{2}{|c|}{$>7$ hari } & & & \\
\hline & $\bar{n}$ & $\%$ & $\mathbf{n}$ & $\%$ & $\mathbf{n}$ & $\%$ & \\
\hline$\geq 3,5 \mathrm{~g} / \mathrm{dl}$ & 18 & $3,9 \%$ & 23 & $56,1 \%$ & 1 & $100 \%$ & \\
\hline$<3,5 \mathrm{~g} / \mathrm{dl}$ & 5 & $5,6 \%$ & 4 & $44,4 \%$ & 9 & $100 \%$ & \\
\hline
\end{tabular}

Berdasarkan Tabel 2 diatas, penderita stroke iskemik dengan kadar albumin serum yang normal, sebagian besar penderita menjalani perawatan dengan lama lebih dari 7 hari (23 subjek, 56,1\%). Sedangkan pada kelompok penderita dengan hipoalbuminemia sebanyak 5 subjek $(55,6 \%)$ menjalani perawatan dengan lama lebih dari 7 hari (tabel 5.2). Dari analisis statistik, tidak didapatkan hubungan yang bermakna antara kadar albumin serum dengan lama rawatan pada penderita stroke iskemik akut $(p=0,751)$

Tabel 3. Hubungan derajat stroke dengan lama rawatan pasien stroke akut

\begin{tabular}{|c|c|c|c|c|c|c|}
\hline \multirow{3}{*}{$\begin{array}{l}\text { Derajat } \\
\text { Stroke }\end{array}$} & \multicolumn{4}{|c|}{ Lama rawatan } & \multirow{3}{*}{ p } & \multirow{3}{*}{ OR } \\
\hline & \multicolumn{2}{|c|}{$\leq 7$ hari } & \multicolumn{2}{|c|}{$>7$ hari } & & \\
\hline & $\bar{n}$ & $\%$ & $\mathbf{n}$ & $\%$ & & \\
\hline Ringan & 18 & $75,0 \%$ & 6 & $25,0 \%$ & $<0 \cap 01$ & 126 \\
\hline $\begin{array}{l}\text { Sedang- } \\
\text { berat }\end{array}$ & 5 & $19,2 \%$ & 21 & $80,8 \%$ & & \\
\hline
\end{tabular}

Berdasarkan pengelompokan subjek menurut skor NIHSS, pada penderita stroke dengan derajat ringan sebagian besar memiliki lama rawatan kurang atau sama dengan 7 hari (18 subjek, 75\%), sedangkan pada 26 subjek dengan derajat stroke sedang-berat sebanyak 21 penderita $(80,8 \%)$ lama rawatannya lebih dari 7 hari.

Hasil analisis statistik, didapatkan hubungan yang bermakna antara derajat stroke dengan lama rawatan pada pasien stroke iskemik akut $(p<0,001)$. Hasil analisis statistik juga menunjukkan nilai odds ratio adalah 12,6 , yang maknanya pasien dengan derajat stroke sedang-berat memiliki risiko perawatan lebih lama sebesar 12,6 kali dibanding penderita stroke derajat ringan.

Tabel 4. Hubungan komplikasi dengan lama rawatan pasien stroke iskemik akut

\begin{tabular}{ccccccc}
\hline \multirow{2}{*}{ Komplikasi } & \multicolumn{6}{c}{ Lama rawatan } \\
\cline { 2 - 5 } & \multicolumn{2}{c}{$\leq 7$ hari } & \multicolumn{2}{c}{$>7$ hari } & $\mathrm{p}$ & OR \\
\cline { 2 - 6 } & $\mathrm{n}$ & $\%$ & $\mathrm{n}$ & $\%$ & & \\
\hline Tidak ada & 22 & $59,5 \%$ & 15 & $40,5 \%$ & $<0.001$ & 17,6 \\
Ada & 1 & $7,7 \%$ & 12 & $92,3 \%$ & & \\
\hline
\end{tabular}

Pada penelitian ini didapatkan 13 subjek penelitian yang memiliki komplikasi selama masa rawatan. Dari 37 pasien yang tidak mengalami komplikasi, lebih dari sebagiannya (59,5\%) dirawat kurang dari 7 hari. Dari 13 orang dengan komplikasi, 92,3\% pasien dirawat lebih dari 7 hari. Analisis statistik menyatakan terdapat hubungan bermakna antara komplikasi dengan lama rawatan pada pasien stroke iskemik akut $(p<0,001)$. Dari analisis ini juga didapatkan nilai odds ratio 17,6 , yang bermakna pasien stroke dengan komplikasi memiliki risiko perawatan lebih lama sebesar 17,6 kali dibanding penderita stroke tanpa komplikasi

Tabel 5. Hubungan faktor risiko dengan lama rawatan pasien stroke iskemik akut

\begin{tabular}{|c|c|c|c|c|c|c|c|}
\hline \multirow{3}{*}{$\begin{array}{c}\text { Faktor } \\
\text { risiko }\end{array}$} & \multicolumn{4}{|c|}{ Lama rawatan } & \multirow{2}{*}{\multicolumn{2}{|c|}{ Total }} & \multirow{3}{*}{$\mathbf{p}$} \\
\hline & \multicolumn{2}{|c|}{$\leq 7$ hari } & \multicolumn{2}{|c|}{$>7$ hari } & & & \\
\hline & $\bar{n}$ & $\%$ & $\mathbf{n}$ & $\%$ & $\mathbf{n}$ & $\%$ & \\
\hline Tidak & 6 & $37,5 \%$ & 10 & $62,5 \%$ & 16 & $100 \%$ & \multirow{2}{*}{0,76} \\
\hline Ada & 17 & $50,0 \%$ & 17 & $50,0 \%$ & 34 & $100 \%$ & \\
\hline
\end{tabular}


Pada 34 pasien stroke dilihat dari ada tidaknya faktor risiko, sebagian pasien dirawat kurang dari 7 hari dan sebagian lagi lebih dari sama dengan 7 hari. Hasil analisis statistik menunjukkan tidak terdapat hubungan bermakna antara faktor risiko dengan lama rawatan $(p=0,76)$.

\section{PEMBAHASAN}

Pada penelitian ini rerata lama rawatan pasien stroke iskemik akut adalah 14 hari.Dari 50 sampel yang diteliti, terdapat 27 pasien dengan lama rawatan memanjang (>7 hari). Penelitian yang dilakukan di RSUP Cipto Mangunkusomo Jakarta pada tahun 2010 juga menyatakan bahwa rata-rata lama rawatan pasien stroke iskemik adalah 14 (S.D 7,5) hari. ${ }^{8}$ Penelitian yang dilakukan Corso et al (2014) juga menemukan rata-rata lama rawatan yang hampir sama yaitu 15,8 hari. Rerata lama rawatan bervariasi pada berbagai negara dan dinilai dapat mencerminkan kualitas organisasi pelayanan kesehatan. ${ }^{9}$ Perbedaan ini dapat disebabkan oleh perbedaan faktor yang dapat memperpanjang lama rawatan antara lain etiologi yang mendasari stroke, terapi pembedahan serta terapi lainnya yang digunakan. ${ }^{10}$

Rerata kadar albumin serum pada penelitian ini adalah $3,86 \mathrm{~g} / \mathrm{dl}$. Hasil penelitian ini berbeda dengan yang didapatkan oleh Dziedzic et al pada tahun 2007. Mereka mengukur kadar albumin serum pada 759 sampel stroke iskemik akut dan mendapatkan rerata kadar albumin serum 3,55 g/dl. ${ }^{6}$ Perbedaan ini disebabkan oleh jumlah sampel yang mereka dapatkan jauh lebih besar dan persentase penderita hipoalbumin pada penelitian tersebut adala 45,5\%. Hasil yang mendekati rerata penelitian kami adalah penelitian yang dilakukan oleh Kasundra \& Sood (2014), yaitu 3,81g/dl. Mereka melakukan penelitian pada 50 sampel penderita stroke iskemik akut dan mendapatkan 16 orang dengan hipoalbuminemia. ${ }^{11}$

Hasil penelitian ini tidak menemukan adanya hubungan yang bermakna antara kadar albumin serum dengan lama rawatan pada penderita stroke iskemik akut $(p=0,72)$. Hasil penelitian ini serupa dengan penelitian yang dilakukan oleh Martineau et al(2005), dimana mereka juga tidak menemukan adanya hubungan antara kadar albumin serum dengan lama rawatan $(p=0,893) .{ }^{12}$ Penelitian yang dilakukan oleh Ginsberg et al (2013) juga tidak menemukan adanya pengaruh signifikan dari pemberian albumin $25 \%$ terhadap outcome pasien stroke iskemik akut. ${ }^{13}$

Hasil penelitian yang berbeda didapatkan pada studi oleh Turhan et al (2006), dimana mereka meneliti 68 pasien stroke iskemik yang berusia lebih dari 65 tahun. Mereka mendapatkan kadar albumin serum berhubungan dengan lamanya rawatan dan gangguan fungsional. Kesimpulan dari penelitian tersebut adalah kadar albumin serum merupakan indikator penting untuk menilai outcome fungsional dan lama rawatan pasien stroke iskemik usia tua. ${ }^{14}$ Perbedaan yang kami dapatkan pada penelitian ini kemungkinan disebabkan usia sampel kami yang jauh lebih muda.

Serum albumin diatur oleh faktor-faktor yang mempengaruhi sintesis protein, seperti kebocoran pada ruang ekstravaskular dan asupan makanan. Dalam praktek klinis, serum albumin sering dianggap sebagai penanda status gizi dan protein fase negatif yang konsentrasinya menurun selama cedera dan sepsis. Selain itu, telah dilaporkan bahwa kekurangan energi protein setelah stroke akut merupakan faktor risiko untuk hasil yang buruk memperburuk prognosis Pasien stroke usia lanjut secara signifikan memiliki serum albumin lebih rendah ${ }^{15,16}$ Subjek penelitian ini adalah populasi yang relatif muda, sehingga sulit untuk menemukan pasien dengan serum albumin yang relatif rendah.

Pada penelitian ini didapatkan hubungan bermakna antara derajat stroke dengan lama rawatan $(p<0,001)$. Tujuh puluh lima persen pasien dengan derajat stroke ringan memiliki masa rawatan $\leq 7$ hari, sementara $80,8 \%$ pasien dengan derajat stroke sedang-berat memiliki masa rawatan $>7$ hari. Hal ini sama dengan penelitian Mohamed et al (2015) yang membuktikan bahwa NIHSS adalah prediktor independen yang dapat memprediksi lama rawatan, biaya rumah sakit, hasil klinis, dan waktu pulang. ${ }^{17}$ Penelitian yang dilakukan Zandieh et al (2013) mendaptkan bahwa NIHSS yang diukur pada hari pertama mampu memprediksi outcome dan mengurangi lama rawatan. ${ }^{18}$ 
Menurut penelitian yang dilakukan Wartenberg et al (2011), pasien dengan stroke berat lebih rentan terhadap infeksi serius selama tinggal di rumah sakit yang turut serta memperpanjang lama rawatan. ${ }^{19}$

Terdapat hubungan signifikan antara komplikasi dengan lama rawatan pada penderita stroke iskemik akut pada penelitian ini $(p<0,001)$. Dari 13 subjek penelitian yang memiliki komplikasi, 12 diantaranya $(92,3 \%)$ memiliki lama rawatan lebih dari tujuh hari.

Penelitian yang dilakukan oleh Ingeman et al (2011) juga mendapatkan hasil yang sama. Mereka menyimpulkan bahwa seluruh komplikasi medis selama masa rawaran berhubungan dengan lama rawatan pada pasien stroke iskemik akut, bahkan setelah dilakukan penyesuaian dengan faktor-faktor pengganggu pada penelitian. ${ }^{5}$ Hasil yang sama juga didapatkan oleh penelitian oleh Arboix et al (2012), dimana komplikasi medis selama masa rawatan mempengaruhi durasi rawatan. ${ }^{4}$

Hubungan antara faktor risiko dengan lama rawatan diuji dengan uji chi-square, dimana tidak terdapat hubungan bermakna antara faktor risiko dengan lama rawatan $(p=076)$. Penelitian yang dilakukan sebelumnya juga tidak menemukan adanya korelasi antara faktor risiko dengan lama rawatan pasien stroke iskemik. ${ }^{15}$

Keterbatasan penelitian ini adalah jumlah sampel dengan hipoalbuminemia yang sedikit. Dibanding beberapa penelitian terdahulu yang mendapatkan hasil bermakna, sehingga mungkin dapat mempengaruhi hasil. Usia pada penelitian ini lebih kecil dibandingkan penelitian lain yang menilai hubungan antara kadar albumin serum dengan lama rawatan pada pasien stroke iskemik akut. Oleh karena itu, perlu dilakukan penelitian selanjutnya yang menilai hubungan kadar albumin serum dengan lama rawatan pada penderita stroke iskemik akut dengan jumlah sampel hipoalbuminemia yang lebih banyak dan usia yang lebih tua, sesuai penelitian sebelumnya.

\section{SIMPULAN}

Tidak didapatkan hubungan bermakna antara kadar albumin serum dengan lama rawatan pasien stroke iskemik akut. Akan tetapi didapatkan hubungan bermakna antara derajat stroke dengan lama rawatan dan komplikasi dengan lama rawatan.

Faktor risiko tidak memiliki hubungan bermakna dengan lama rawatan, oleh karena itu perlu diberikan perhatian khusus pada pasien stroke iskemik dengan derajat stroke sedang-berat ataupun pasien rawatan dengan komplikasi untuk mempersingkat rawatan.

\section{UCAPAN TERIMA KASIH}

Terima kasih disampaikan kepada seluruh PPDS IImu Penyakit Saraf FK Universitas Andalas yang telah membantu penyelesaian artikel ini.

\section{DAFTAR PUSTAKA}

1. Stroke Forum. Epidemiology of stroke [serial online] 2015 (diunduh 22 Januari 2015). Tersedia dari: URL: HYPERLINK http://www.strokeforum. com/strokebackground/epidemiology.html

2. Price SA, Wilson LM, editor (penyunting). Patofisiologi: konsep klinis proses-proses penyakit. Edisi ke-6. Jakarta: EGC; 2014.

3. Li Y, Liu H, Wang J, Yu GP, Ma XM, Liang MH et al. Variable lengths of stay among ischemic stroke subtypes in chinese general teaching hospitals. Stroke. 2012;7(9),2012:1-8.

4. Arboix A, Massons J, Eroles LG, Targa C, Oliveres $\mathrm{M}$, Comes E. Clinical predictors of prolonged hospital stay after acute stroke: relevance of medical complications. Clin Med. 2012;3:502-7.

5. Ingeman A, Andersen G, Hundborg HH, Svendsen ML. In hospital medical complications, length of stay, and mortality among stroke unit patients. Stroke. 2011; 42:3214-8.

6. Dziedzic T, Pera J, Slowik A, Gryz-Kurek EA, Szczudlik A. Hypoalbuminemia In acute ischemic stroke patients: frequency and correlates. Clin Nutr. 2007;61:1318-22.

7. Babu MS, Kaul S, Dadheech S, Rajeshwar K, Jyoth A, Munshi A, et al,. Serum albumin levels in ischemic stroke and its subtypes: correlation with clinical outcome. Nutrition. 2013;29:872-5.

8. Roza R. Lama hari rawat pasien stroke di RSUPN Cipto Mangunkusumo dan faktor-faktor yang mempengaruhi. (skripsi). Jakarta: Fakultas Kedokteran Universitas Indonesia; 2010. 
9. Corso G, Bottacchi E, Tosi P, Caligiana P, Lia C, Morosini MV, Dalmasso P. Outcome predictors in first-ever ischemic stroke patients:a populationbased study. Otolaryngology. 2014; Article ID 904647:1-8.

10. Huang YC, Hu JC, MD, Lee TH, Yang JT, Weng $\mathrm{HH}, \mathrm{MD}$, Lin LC, et al. The impact factors on the cost and length of stay among acute ischemic stroke. Stroke Cerebrovasc. 2013;22(7):152-8.

11. Kasundra G, Sood I. Prognostic significance of serum albumin levels in acute ischemic stroke. NJIRM. 2014;5(2):1-4.

12. Martineau J, Bauer JD, Isenring E, Sarah. Malnutrition determined by the patient-generated subjective global assessment is associated with poor outcomes in acute stroke patients. Clin Nutr. 2005;24(6):1073-7.

13. Ginsberg MD, Palesch YY, Hill MD, Martin RH, Moy CS, Barson WG, et al. High-dose albumin treatment for acute ischaemic stroke (alias) part 2: a randomised, double-blind, phase 3 , placebocontrolled trial. Neurology. 2013;12(11):1049-58.

14. Turhan N, Saracgil N, Oztop P, Bayramoğlu M. Serum albumin and comorbidity relative to rehabitlitation outcome in geriatric stroke and possible links with stroke etiology. Int $\mathrm{J}$ Rehabil Res. 2006;19(1):81-5.

15. Perez FJA, Branco MC, Sabin JA. Albumin level and stroke, potential association between lower albumin level and cardioembolic aetiology. Neurosience. 2010:1-8.

16. Kisialiou A, Pelone G, Carrizzo A, Grillea G, Trimarco $\mathrm{V}$, Marino $\mathrm{M}$. Blood biomarkers role in acute ischemic stroke patients:higher is worse or better?. Immunity Ageing. 2012; 9:22-32.

17. Mohamed W, Bhattacharya P, Shankar L, Chaturvedi S, Madhavan. Which comorbidities and complications predict ischemic stroke recovery and length of stay? Neurologist. 2015;20(2):27-32.

18. Zandieh A, Kahaki ZZ, Sadeghian H, Fakhri M, Pourashraf M, Parviz S. A simple risk score for early ischemic stroke mortality derived from National Institutes of Health Stroke Scale: A discriminant analysis. Clin Neurol Neurosurg. 2013; 115:1036-9.

19. Wartenberg KE, Stoll A, Funk A, Meyer A, Schmidt $\mathrm{JM}$, Berrouschot J. Infection after acute ischemic stroke: risk factors, biomarkers, and outcome. Stroke Res Treat. 2011; Article ID 830614:1-8. 